Correspondence to: Professor B K Nicholson

Chemistry Department

University of Waikato

Private Bag 3105

Hamilton

New Zealand

Email: b.nicholson@waikato.ac.nz

Fax: 6478384219

\title{
Manganese carbonyl-mediated reactions of azabutadienes with phenylacetylene, methyl acrylate and other unsaturated molecules.
}

Wade J. Mace, Lyndsay Main*, Brian K Nicholson* and Daniel J. van de Pas.

Department of Chemistry, University of Waikato, Private Bag 3105, Hamilton, New Zealand.

\section{Synopsis}

$\mathrm{PhCH}_{2} \mathrm{Mn}(\mathrm{CO})_{5}$ reacts with 1,4-di-aryl-1-aza-1,3-butadienes in the presence of unsaturated substrates to give products based on a cyclomanganated intermediate.
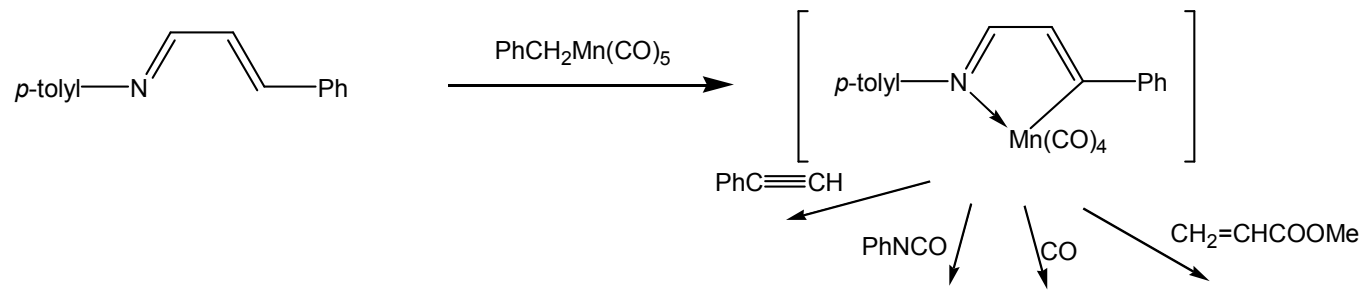


\begin{abstract}
.
Reaction of $\mathrm{PhCH}_{2} \mathrm{Mn}(\mathrm{CO})_{5}$ with 1,4-di-aryl-1-aza-1,3-butadienes gave substituted pyrrolinonyl rings which were $\eta^{4}$-coordinated to a $\mathrm{Mn}(\mathrm{CO})_{3}$ group. These are formed by intramolecular CO insertion into a (non-isolated) cyclomanganated intermediate, followed by cyclisation. Other unsaturated reagents $\left(\mathrm{PhC} \equiv \mathrm{CH}, \mathrm{CH}_{2}=\mathrm{CHCOOMe}\right.$, $\mathrm{PhNCO}$ ) gave products arising from insertion of these, including a structurally characterised tri-aryl- $\eta^{5}$-azacyclohexadienyl-Mn(CO) 3 complex from the reaction with the alkyne.
\end{abstract}

\title{
1. Introduction.
}

Cyclomanganation of organic substrates to give complexes of the form $\mathbf{1}$ has proved to be a general process [1]. Substrates that have been examined include aryl- and hetero-aryl ketones [2] and imines [3], benzylamines [4], triphenylphosphine chalcogenides [5] and triphenylphosphine imines [6]. These complexes undergo a series of interesting reactions involving the $\mathrm{Mn}-\mathrm{C}$ bond with alkenes [7], alkynes [8], organic isocyanates [9], sulfur dioxide [10] and carbon disulfide [11]. More recently, cyclomanganation studies have been extended beyond aryl substrates to reactions involving $\alpha, \beta$-unsaturated ketones (chalcones) where compounds of the type 2 could be formed [12]. These also reacted with alkynes, in particular, to give novel products, including $\eta^{5}$-pyranyl- and $\eta^{5}$-cycloheptadienyl-Mn(CO) $)_{3}$ derivatives [13].

1-Azabutadienes, $\mathbf{3}$, are pseudo-iso-electronic with chalcones so appeared to be a potential source of new organomanganese chemistry. While there has been extensive use of azabutadienes as $\eta^{4}$-butadiene analogues, most of the previously reported cyclometallated azabutadiene compounds have been prepared indirectly. These include 
di- and tetra-ruthenium compounds [14], the di-manganese compound 4 (from $\mathrm{Mn}_{2}(\mathrm{CO})_{9}(\mathrm{CNR})$ and DMAD [15] ), and the manganese complex 5 (from $\mathrm{ClC}_{6} \mathrm{H}_{5} \mathrm{CH}_{2} \mathrm{C}(\mathrm{O}) \mathrm{Mn}(\mathrm{CO})_{4}\left(\mathrm{CNC}_{6} \mathrm{H}_{4} \mathrm{CH}_{3}\right)$ and $\left.\mathrm{CF}_{3} \mathrm{CCCF}_{3}\right)$ [16]. Only some orthopalladiated examples $\mathbf{6}$ have involved direct cyclometallation of an azabutadiene [17].

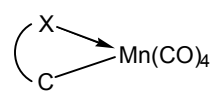

1

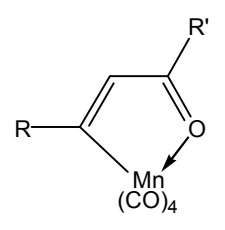

2
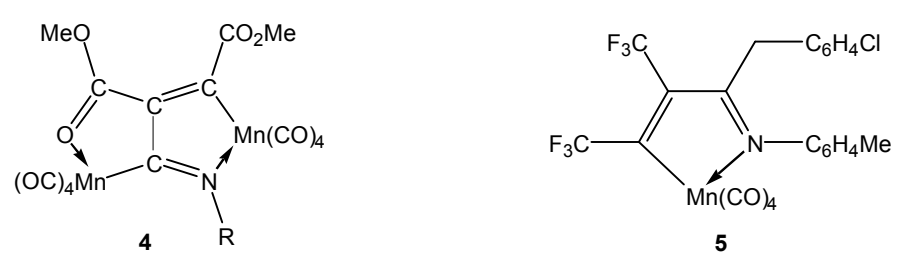

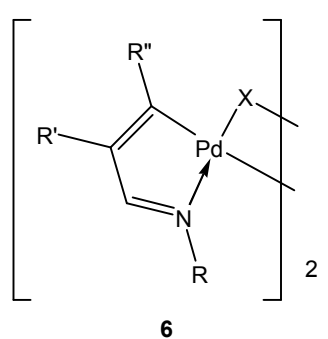

We now report attempts to prepare directly orthomanganated azabutadiene complexes, and their reactivity towards some unsaturated molecules.

\section{Experimental Section}

\subsection{General}

Electrospray mass spectra were recorded on a VG Platform II spectrometer, operated as detailed elsewhere [18]. Spectra were run at a cone voltage of $20 \mathrm{~V}$ unless otherwise specified, and in some cases $\mathrm{Na}[\mathrm{OMe}$ ] was added to provide ionisation [19]. NMR spectra were obtained in $\mathrm{CDCl}_{3}$ on a Bruker $\mathrm{AC} 400$ instrument operating under standard conditions, with assignments based on COSY, HSQC and HMBC experiments. IR spectra were recorded on a Digilab FTS-40 instrument. All reactions were carried out under nitrogen, but no precautions to exclude air were taken during work-up. 
The azabutadiene 4-phenyl-1-p-tolyl-1-azabuta-1,3-diene 3a, its 1,4-diphenyl analogue and $\mathrm{PhCH}_{2} \mathrm{Mn}(\mathrm{CO})_{5}$ were prepared by literature routes [20, 21]. PLC and TLC refer to preparative and thin layer chromatography on silica gel (Merck Kieselgel $\left.60 \mathrm{PF}_{254}\right)$.

\subsection{Reactions}

2.2.1 Reaction of 4-phenyl-1-p-tolyl-1-azabuta-1,3-diene with $\mathrm{PhCH}_{2} \mathrm{Mn}(\mathrm{CO})_{5}$.

A solution of the azabutadiene $3 \mathbf{a}(51 \mathrm{mg}, 0.23 \mathrm{mmol})$ and $\mathrm{PhCH}_{2} \mathrm{Mn}(\mathrm{CO})_{5}(80 \mathrm{mg}, 0.28$ mmol) in petroleum spirits $(15 \mathrm{ml})$ was transferred to a Schlenk flask. The solution was heated under reflux for 6.5 hours. The solvent was removed under vacuum, and the residue was dissolved in dichloromethane and chromatographed (PLC), eluting with petroleum spirits/ether (1:1), to afford three fractions. The first fractions contained unreacted starting materials, while the third fraction was collected to afford the $\eta^{4}-1-$ tolyl-3-phenyl-pyrrolin-2-onyl complex 7 which was recrystallised as yellow needles from diethyl ether $(32 \mathrm{mg}, 35 \%)$, m.p. $143^{\circ} \mathrm{C}$. Found: C $62.03, \mathrm{H} 3.64, \mathrm{~N} 3.62 \%$. $\mathrm{C}_{20} \mathrm{H}_{14} \mathrm{MnNO}_{4}$ requires C 63.36, H 3.66, N 3.82\%, M 387. v(C三O) (heptane) 2034(s), 1962(m), 1945(m) $\mathrm{cm}^{-1}$. ESMS: (MeOH/NaOMe, -ve ion) $\mathrm{m} / z 386$ (4\%, [M-H] $), 418$ $(100 \%,[\mathrm{M}+\mathrm{OMe}]) .{ }^{1} \mathrm{H} \mathrm{NMR}: \delta 2.41\left(3 \mathrm{H}, \mathrm{s}, \mathrm{CH}_{3}\right), 5.98\left(1 \mathrm{H}, \mathrm{d},{ }^{3} J_{\mathrm{HH}}=2.4 \mathrm{~Hz}, \mathrm{H} 4\right), 6.23$

$\left(1 \mathrm{H}, \mathrm{d},{ }^{3} J_{\mathrm{HH}}=2.4 \mathrm{~Hz}, \mathrm{H} 5\right), 7.3(4 \mathrm{H}, \mathrm{m}, \mathrm{H} 2 " / \mathrm{H} 3 " / \mathrm{H} 5 " / \mathrm{H} 6 "), 7.3\left(1 \mathrm{H}, \mathrm{t},{ }^{3} J_{\mathrm{HH}}=7.4 \mathrm{~Hz}\right.$, H4'), $7.4\left(2 \mathrm{H}, \mathrm{dd},{ }^{3} J_{\mathrm{HH}}=7.5,7.5 \mathrm{~Hz}, \mathrm{H} 3^{\prime} / \mathrm{H} 5^{\prime}\right), 7.9\left(2 \mathrm{H}, \mathrm{d},{ }^{3} J_{\mathrm{HH}}=7.5 \mathrm{~Hz}, \mathrm{H} 2^{\prime} / \mathrm{H}^{\prime}\right) ;{ }^{13} \mathrm{C}$ NMR : $\delta 21.4\left(\mathrm{CH}_{3}\right), 71.2(\mathrm{C} 3), 78.9$ (C5), 83.1 (C4), 126.2 (C2'/C6'), 126.5 (C2”/C6”), 127.8 (C4'), 129.1 (C3'/C5'), 130.5 (C3”/C5”), 132.2 (C1'), 132.5 (C1”), 140.1 (C4”), $152.4(\mathrm{C} 2), 221.5\left(\mathrm{Mn}(\mathrm{CO})_{3}\right)$

2.2.2 Reaction of 4-phenyl-1-p-tolyl-1-azabuta-1,3-diene and PhC $\equiv C H$ with $\mathrm{PhCH}_{2} \mathrm{Mn}(\mathrm{CO})_{5}$. 
A solution of the azabutadiene $3 \mathrm{a}(52 \mathrm{mg}, 0.23 \mathrm{mmol}), \mathrm{PhC} \equiv \mathrm{CH}(75 \mu \mathrm{L}, 0.68 \mathrm{mmol})$ and $\mathrm{PhCH}_{2} \mathrm{Mn}(\mathrm{CO})_{5}(87 \mathrm{mg}, 0.30 \mathrm{mmol})$ in petroleum spirits $(15 \mathrm{ml})$ was heated to reflux for three hours. The solvent was removed under vacuum, and the residue chromatographed (PLC, 1:1 petroleum spirits/ether) to give three fractions. The first main fraction afforded the azacyclohexadienyl complex $\mathbf{8 a}$ which was recrystallised by vapour diffusion (ether/petroleum spirits) as a cream powder $(94 \mathrm{mg}, 87 \%)$, m.p. $176^{\circ} \mathrm{C} . v(\mathrm{C} \equiv \mathrm{O})$ (petroleum spirits) 2025(s), 1965(m), 1946(m) $\mathrm{cm}^{-1}$. ESMS (MeOH/NaOMe, -ve ion) $m / z 460\left(27 \%,[\mathrm{M}-\mathrm{H}]^{-}\right), 492\left(100 \%,[\mathrm{M}+\mathrm{OMe}]^{-}\right)$.

${ }^{1} \mathrm{H}$ NMR $\delta 2.22\left(3 \mathrm{H}, \mathrm{s}, \mathrm{CH}_{3}\right), 5.01\left(1 \mathrm{H}, \mathrm{d},{ }^{3} J_{\mathrm{HH}}=4.2 \mathrm{~Hz}, \mathrm{H} 6\right), 5.52\left(1 \mathrm{H}, \mathrm{d},{ }^{3} J_{\mathrm{HH}}=4.2\right.$ $\mathrm{Hz}, \mathrm{H} 5), 6.29(1 \mathrm{H}, \mathrm{s}, \mathrm{H} 3), 6.58\left(2 \mathrm{H}, \mathrm{d},{ }^{3} J_{\mathrm{HH}}=8.1 \mathrm{~Hz}, \mathrm{H} 2{ }^{\prime} / \mathrm{H} 6{ }^{\prime}\right), 6.92\left(2 \mathrm{H}, \mathrm{d},{ }^{3} J_{\mathrm{HH}}=8.1\right.$ $\mathrm{Hz}, \mathrm{H} 3^{\prime} / \mathrm{H} 5$ '), $7.30\left(1 \mathrm{H} \mathrm{t},{ }^{3} J_{\mathrm{HH}}=7.3 \mathrm{~Hz}, \mathrm{H} 4\right.$ '), $7.34-7.45$ (5H, m, Ar-H), 7.58 (2H, d, $\left.{ }^{3} J_{\mathrm{HH}}=8.4 \mathrm{~Hz}, \mathrm{H} 2 " / \mathrm{H} 6 ”\right), 7.70\left(2 \mathrm{H}, \mathrm{d},{ }^{3} J_{\mathrm{HH}}=6.8 \mathrm{~Hz}, \mathrm{H} 2 * / \mathrm{H} 6 *\right) ;{ }^{13} \mathrm{C} \mathrm{NMR} \delta 20.8\left(\mathrm{CH}_{3}\right)$, 66.0 (C6), 82.0 (C2), 88.6 (C3), 91.7 (C5), 102.3 (C4), 115.4 (C2'/C6'), 123.9 (C2”/C6”), 127.2 (C2*/C6*), 127.9 (C4”), 128.9 (Ar-H), 129.3 (C3'/C5'), 129.4 (Ar-H), 130.3 (C1'), $136.9(\mathrm{C} 1 *), 138.1\left(\mathrm{Cl}{ }^{\prime}\right), 153.1(\mathrm{C} 4 '), 221.7\left(\mathrm{Mn}(\mathrm{CO})_{3}\right)$.

The second fraction was a mixture of minor products including unreacted azabutadiene. The third fraction (11 mg) was manganese-free, but was not able to be characterized, ESMS (MeOH/NaOMe) $m / z 452(100 \%), 905(27 \%)$ which can be assigned as [M-H] ${ }^{-}$ and $[2 \mathrm{M}-\mathrm{H}]^{-}$respectively for $\mathrm{M}_{\mathrm{r}}=453$.

\subsubsection{Reaction of 1,4-diphenyl-1-azabuta-1,3-diene and $\mathrm{PhC} \equiv \mathrm{CH}$ with $\mathrm{PhCH}_{2} \mathrm{Mn}(\mathrm{CO})_{5}$.} A petroleum spirits $(30 \mathrm{~mL})$ solution containing $\mathrm{PhCH}_{2} \mathrm{Mn}(\mathrm{CO})_{5}(160 \mathrm{mg}, 0.56 \mathrm{mmol})$, diphenylazabutadiene (100 mg, $0.48 \mathrm{mmol})$ and $\mathrm{PhC} \equiv \mathrm{CH}(200 \mu \mathrm{L}, 1.96 \mathrm{mmol})$ was heated under reflux for four hours. The solvent was evaporated and the residue 
chromatographed, eluting with ether/petroleum spirits (1:9). The main band was removed and recrystallised from hot petroleum spirits to give yellow crystals of $\mathbf{8 b},(68 \mathrm{mg}, 31 \%)$. Found: $\mathrm{C} 69.96, \mathrm{H} 4.28, \mathrm{~N} 3.06 \% ; \mathrm{C}_{26} \mathrm{H}_{17} \mathrm{MnNO}_{3}$ requires 69.78, H 4.05, N 3.13\%, M 447. IR (petroleum spirits) $v(\mathrm{C} \equiv \mathrm{O}) 2023(\mathrm{~s}), 1965(\mathrm{~m}), 1946(\mathrm{~m}) \mathrm{cm}^{-1}$. ESMS (MeOH/NaOMe, -ve ion) $\mathrm{m} / \mathrm{z} 446$ (20\%, [M-H] $), 478\left(100 \%,[\mathrm{M}+\mathrm{OMe}]^{-}\right)$. ${ }^{1} \mathrm{H}$ NMR $\delta 5.01\left(1 \mathrm{H}, \mathrm{d},{ }^{3} J_{\mathrm{HH}}=4.2 \mathrm{~Hz}, \mathrm{H} 6\right), 5.52\left(1 \mathrm{H}, \mathrm{d},{ }^{3} J_{\mathrm{HH}}=4.2 \mathrm{~Hz}, \mathrm{H} 5\right), 6.29(1 \mathrm{H}, \mathrm{s}$, H3), 6.63-7.86 (Ar-H); ${ }^{13} \mathrm{C}$ NMR $\delta 65.3$ (C6), 81.4 (C2), 88.7 (C3), 91.7 (C5), 102.4 (C4), 115.2-155.3 (Ar-C), $221.5\left(\mathrm{Mn}(\mathrm{CO})_{3}\right)$.

\subsubsection{Reaction of 4-phenyl-1-p-tolyl-1-azabuta-1,3-diene and $\mathrm{CH}_{2}=\mathrm{CHCO}_{2} \mathrm{Me}$ with} $\mathrm{PhCH}_{2} \mathrm{Mn}(\mathrm{CO})_{5}$.

A solution of the azabutadiene $3 \mathbf{a}(53 \mathrm{mg}, 0.24 \mathrm{mmol}), \mathrm{CH}_{2}=\mathrm{CHCO}_{2} \mathrm{Me}(115 \mu \mathrm{L}, 1.2$ mmol) and $\mathrm{PhCH}_{2} \mathrm{Mn}(\mathrm{CO})_{5}(79 \mathrm{mg}, 0.28 \mathrm{mmol})$ in petroleum spirits $(15 \mathrm{ml})$ was transferred to a Schlenk flask under nitrogen. The solution was heated to reflux for 2 hours before the solvent was removed under vacuum. The residue was chromatographed (PLC, 1:1 ethyl acetate/petroleum spirits) giving three fractions. The first and last were minor fractions containing a mixture of products (no further purification was attempted on these fractions). The second fraction contained the main product $\mathbf{9}$, recrystallised as a yellow powder by vapour diffusion (benzene/hexane) $(28 \mathrm{mg}, 39 \%)$, m.p. $148^{\circ} \mathrm{C}$. Found C 63.35, H 4.73, N 3.27; $\mathrm{C}_{23} \mathrm{H}_{20} \mathrm{MnNO}_{3}$ requires C 62.03, H. 4.53, N 3.15\%, M 445. IR $\left(\mathrm{CH}_{2} \mathrm{Cl}_{2}\right) v(\mathrm{C} \equiv \mathrm{O}) 2017(\mathrm{~s}), 1933(\mathrm{~m}, \mathrm{br}) \mathrm{cm}^{-1}, v(\mathrm{C}=\mathrm{O}) 1734 \mathrm{~cm}^{-1}$. ESMS $(\mathrm{MeOH},+v e$ ion) $m / z 308\left(100 \%,\left[\mathrm{M}-\mathrm{Mn}(\mathrm{CO})_{3}+2 \mathrm{H}\right]^{+}\right), 468\left(17 \%,[\mathrm{M}+\mathrm{Na}]^{+}\right), 913\left(11 \%,[2 \mathrm{M}+\mathrm{Na}]^{+}\right)$. ${ }^{1} \mathrm{H}$ NMR $\delta 2.23\left(1 \mathrm{H}, \mathrm{d},{ }^{3} J_{\mathrm{HH}}=11.8 \mathrm{~Hz}, \mathrm{H} 2\right), 2.40(3 \mathrm{H}, \mathrm{s}, \mathrm{Me}), 3.33\left(1 \mathrm{H}, \mathrm{d},{ }^{3} J_{\mathrm{HH}}=22.3\right.$ $\mathrm{Hz}, \mathrm{H} 5), 3.72\left(1 \mathrm{H}, \mathrm{d},{ }^{3} J_{\mathrm{HH}}=22.2 \mathrm{~Hz}, \mathrm{H} 5\right), 3.83(3 \mathrm{H}, \mathrm{s}, \mathrm{OMe}), 6.43\left(1 \mathrm{H}, \mathrm{d},{ }^{3} J_{\mathrm{HH}}=11.7\right.$ 
$\mathrm{Hz}, \mathrm{H} 3), 7.04\left(2 \mathrm{H}, \mathrm{d},{ }^{3} J_{\mathrm{HH}}=8.1 \mathrm{~Hz}, \mathrm{H} 2 ” / \mathrm{H} 6 ”\right), 7.22\left(2 \mathrm{H}, \mathrm{d},{ }^{3} J_{\mathrm{HH}}=8.1 \mathrm{~Hz}, \mathrm{H} 3 " / \mathrm{H} 5 ”\right)$, $7.23\left(1 \mathrm{H}, \mathrm{m}, \mathrm{H} 4^{\prime}\right), 7.39$ (2H, m, H3'/H5'), $7.53(1 \mathrm{H}, \mathrm{s}, \mathrm{H} 6), 7.66\left(2 \mathrm{H}, \mathrm{m}, \mathrm{H} 2^{\prime} / \mathrm{H}^{\prime}\right){ }^{\prime}{ }^{13} \mathrm{C}$ NMR $\delta 21.1(\mathrm{Me}), 44.7$ (C5), 51.6 (OMe), 59.9 (C2), 90.5 (C4), 102.2 (C3), 120.7 (C2"/C6”), 126.5 (C2'/C6'), 126.5 (C4'), 128.7 (C3'/C5'), 129.9 (C3"/C5”), 137.6 (C4”), 145.7 (C1'), 150.6 (C1”), 174.7 (C1), 176.4 (C6)

\subsubsection{Reaction of 4-phenyl-1-p-tolyl-1-azabuta-1,3-diene and PhNCO with} $\mathrm{PhCH}_{2} \mathrm{Mn}\left(\mathrm{CO}_{5}\right.$.

A solution of the azabutadiene 3a (53 $\mathrm{mg}, 0.24 \mathrm{mmol}), \mathrm{PhNCO}(80 \mu \mathrm{L}, 0.74 \mathrm{mmol})$ and $\mathrm{PhCH}_{2} \mathrm{Mn}(\mathrm{CO})_{5}(71 \mathrm{mg}, 0.25 \mathrm{mmol})$ in petroleum spirits $(15 \mathrm{ml})$ was heated to reflux for 2 hours before the solvent was removed under vacuum. The residue was chromatographed (PLC, 1:4 ethyl acetate/petroleum spirits) to give four fractions, the first two of which were minor fractions containing unreacted starting materials. The third fraction was collected to afford $\mathbf{1 0}(24 \mathrm{mg}, 30 \%)$ as a yellow solid. IR $\left(\mathrm{CH}_{2} \mathrm{Cl}_{2}\right) v(\mathrm{C}=\mathrm{O})$ 1715(br) $\mathrm{cm}^{-1}$. ESMS (MeCN, +ve ion) $\mathrm{m} / z 341\left(100 \%,[\mathrm{M}+\mathrm{H}]^{+}\right), 363\left(45 \%,[\mathrm{M}+\mathrm{Na}]^{+}\right)$, $681\left(43 \%,[2 \mathrm{M}+\mathrm{H}]^{+}\right), 703\left(20 \%,[2 \mathrm{M}+\mathrm{Na}]^{+}\right), 1043\left(8 \%,[3 \mathrm{M}+\mathrm{Na}]^{+}\right),{ }^{1} \mathrm{H}$ NMR $\delta 2.27$ $\left(3 \mathrm{H}, \mathrm{s}, \mathrm{CH}_{3}\right), 3.90(1 \mathrm{H}, \mathrm{s}, \mathrm{NH}), 6.05\left(1 \mathrm{H}, \mathrm{d},{ }^{3} J_{\mathrm{HH}}=2.0 \mathrm{~Hz}, \mathrm{H} 5\right), 6.67\left(2 \mathrm{H}, \mathrm{d},{ }^{3} J_{\mathrm{HH}}=8.4\right.$ $\mathrm{Hz}, \mathrm{H} 2^{\prime} / \mathrm{H} 6$ '), $7.01\left(2 \mathrm{H}, \mathrm{d},{ }^{3} J_{\mathrm{HH}}=8.3 \mathrm{~Hz}, \mathrm{H} 3^{\prime} / \mathrm{H} 5^{\prime}\right), 7.22\left(1 \mathrm{H}, \mathrm{t},{ }^{3} J_{\mathrm{HH}}=7.4 \mathrm{~Hz}, \mathrm{H} 4^{\prime \prime}\right)$, $7.30\left(1 \mathrm{H}, \mathrm{d},{ }^{3} \mathrm{~J}_{\mathrm{HH}}=2.0 \mathrm{~Hz}, \mathrm{H} 4\right), 7.39(2 \mathrm{H}, \mathrm{m}, \mathrm{H} 3 ” / \mathrm{H} 5 ”), 7.43(2 \mathrm{H}, \mathrm{m}, \mathrm{H} 3 * / \mathrm{H} 5 *), 7.46$ $(1 \mathrm{H}, \mathrm{m}, \mathrm{H} 4 *), 7.58\left(2 \mathrm{H}, \mathrm{d},{ }^{3} J_{\mathrm{HH}}=7.6 \mathrm{~Hz}, \mathrm{H} 2 " / \mathrm{H} 6 "\right), 7.95\left(2 \mathrm{H}, \mathrm{d},{ }^{3} J_{\mathrm{HH}}=6.3 \mathrm{~Hz}\right.$, H2*/H6*); ${ }^{13} \mathrm{C}$ NMR $\delta 20.8\left(\mathrm{CH}_{3}\right), 70.9$ (C5), 115.9 (C2'/C6'), 123.4 (C2”/C6”), 125.8 (C4"), 127.9 (C2*/C6*), 128.9 (C3*/C5*), 129.4 (C3"/C5”), 129.5 (C4*), 129.7 (C1'), 130.3 (C3'/C5'), 131.0 (C1*), 136.8 (C1”), 137.9 (C3), 138.2 (C4), 142.5 (C4'), 168.2 (C2) 
The fourth fraction afforded $11(33 \mathrm{mg}, 30 \%$ yield $)$ as a dark yellow solid, m.p. $=192^{\circ} \mathrm{C}$.

IR (heptane) $v(\mathrm{C}=\mathrm{O}, \mathrm{C}=\mathrm{N}) 1718,1703,1676 \mathrm{~cm}^{-1}$. ESMS $(\mathrm{MeOH},+v e$ ion $) \mathrm{m} / z 482$ $\left(100 \%,[\mathrm{M}+\mathrm{Na}]^{+}\right), 941\left(36 \%,[2 \mathrm{M}+\mathrm{Na}]^{+}\right) .{ }^{1} \mathrm{H} \mathrm{NMR} \delta 2.35\left(3 \mathrm{H}, \mathrm{s}, \mathrm{CH}_{3}\right), 6.07(\mathrm{CH})$, 6.78-7.82 (Ar-H), $8.96(\mathrm{NH}) ;{ }^{13} \mathrm{C}$ NMR $\delta 21.5\left(\mathrm{CH}_{3}\right), 67.6(\mathrm{CH}), 120.2-140.4(\mathrm{Ar}-\mathrm{H}$, Ar), $153.8(\mathrm{C}=\mathrm{N}), 154.6(\mathrm{C}=\mathrm{O}), 168.0(\mathrm{C}=\mathrm{O})$

\subsubsection{Attempted reaction of 4-phenyl-1-p-tolyl-1-azabuta-1,3-diene and Bu ${ }^{t} N C$ with} $\mathrm{PhCH}_{2} \mathrm{Mn}(\mathrm{CO})_{5}$.

A mixture of the azabutadiene $3 \mathbf{a}(52 \mathrm{mg}, 0.24 \mathrm{mmol}), \mathrm{Bu}^{\mathrm{t}} \mathrm{NC}(200 \mu \mathrm{L}, 1.8 \mathrm{mmol})$ and $\mathrm{PhCH}_{2} \mathrm{Mn}(\mathrm{CO})_{5}(88 \mathrm{mg}, 0.31 \mathrm{mmol})$ in petroleum spirits $(15 \mathrm{ml})$ was heated to reflux for 2 hours before the solvent was removed under vacuum. The residue was chromatographed (PLC, 1:1 petroleum spirits/dichloromethane) to give three fractions. The first fraction was unreacted azabutadiene, while the second was collected to afford 12, recrystallised as yellow crystals from hexane ( $15 \mathrm{mg}, 10 \%$ yield), m.p. $96^{\circ} \mathrm{C}$. IR (heptane) $v(\mathrm{C} \equiv \mathrm{N}) 2135 \mathrm{~cm}^{-1}, v(\mathrm{C} \equiv \mathrm{O}) 1990(\mathrm{~m}), 1939(\mathrm{~m}) \mathrm{cm}^{-1}, v(\mathrm{C}=\mathrm{O}), v(\mathrm{C}=\mathrm{N}) 1713$, $1679 \mathrm{~cm}^{-1}$. ESMS (MeOH, +ve ion) $\mathrm{m} / z 480\left(100 \%,[\mathrm{M}+\mathrm{H}]^{+}\right) .{ }^{1} \mathrm{H}$ NMR $\delta 1.31(9 \mathrm{H}, \mathrm{s}$, $\left.\mathrm{Bu}^{\mathrm{t}}\right), 1.39\left(9 \mathrm{H}, \mathrm{s}, \mathrm{Bu}^{\mathrm{t}}\right), 1.46\left(9 \mathrm{H}, \mathrm{s}, \mathrm{Bu}^{\mathrm{t}}\right), 3.83\left(1 \mathrm{H}, \mathrm{d}^{2}{ }^{2} \mathrm{HH}=14.1 \mathrm{~Hz}, \mathrm{H} 3\right), 4.27(1 \mathrm{H}, \mathrm{d}$, $\left.{ }^{2} J_{\mathrm{HH}}=14.1 \mathrm{~Hz}, \mathrm{H} 3\right), 7.17$ (2H, m, H3'/H5'), 7.18 (1H, m, H4'), 7.23 (2H, m, H2'/H6');

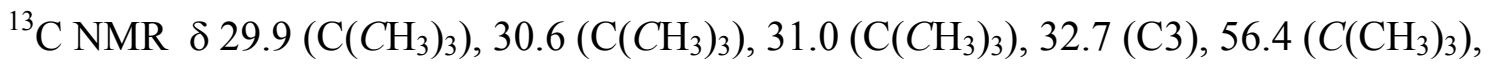

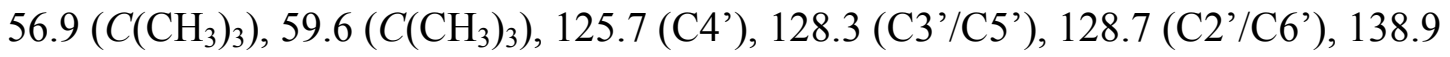
(C1'), 186.2 (C1), 194.8 (C2), 217.0, 221.5 224.4 (Mn-CO, Mn-CNBu')

ESMS determined that the third fraction contained a mixture of $\left[\mathrm{Mn}\left(\mathrm{CNBu}^{t}\right)_{6}\right]^{+}$and $\left[\mathrm{Mn}\left(\mathrm{CNBu}^{\mathrm{t}}\right)_{5}(\mathrm{CO})\right]^{+}$species, and was not analysed further.

2.2.8 Reaction of 4-phenyl-1-p-tolyl-1-azabuta-1,3-diene and $\mathrm{CS}_{2}$ with $\mathrm{PhCH}_{2} \mathrm{Mn}(\mathrm{CO})_{5}$. 
$\mathrm{PhCH}_{2} \mathrm{Mn}(\mathrm{CO})_{5}(81 \mathrm{mg}, 0.284 \mathrm{mmol})$, the azabutadiene $3 \mathbf{a}(54 \mathrm{mg}, 0.243 \mathrm{mmol})$ and $\mathrm{CS}_{2}(5 \mathrm{ml})$ were transferred to an ampoule which was sealed under vacuum. The ampoule was heated to $85^{\circ} \mathrm{C}$ in a Carius tube for 48 hours. Small yellow crystals of $\mathbf{1 3}(2 \mathrm{mg}, 3 \%)$ crystallised from the cooled reaction mixture, and were identified by ESMS and IR [11]. TLC of the remaining reaction mixture showed a multitude of products which were not further investigated.

\subsection{X-ray crystallography}

X-ray intensity data were collected on a Siemens SMART CCD diffractometer using standard procedures and software. Empirical absorption corrections were applied (SADABS [22]). Structures were solved by direct methods and developed and refined on $\mathrm{F}^{2}$ using the SHELX programmes [23]. Hydrogen atoms were included in calculated positions

\subsubsection{Structure of the $\eta^{4}$-pyrrolinonyl complex 7}

Yellow needle crystals of 7 were obtained from diethyl ether.

Crystal data: $\mathrm{C}_{20} \mathrm{H}_{14} \mathrm{MnNO}_{4}, \mathrm{M}=387.26$, monoclinic, space group $\mathrm{C} 2 / \mathrm{c}, \mathrm{a}=24.314(8), \mathrm{b}$ $=11.199(4), \mathrm{c}=16.664(5) \AA, \beta=131.33(3)^{\circ}, \mathrm{U} 3407.1(19) \AA^{3}, \mathrm{~T} 168 \mathrm{~K}, \mathrm{Z}=8, \mathrm{D}_{\text {calc }}=$ $1.510 \mathrm{~g} \mathrm{~cm}^{-3}, \mu(\mathrm{Mo}-\mathrm{K} \alpha)=0.80 \mathrm{~mm}^{-1}, \mathrm{~F}(000) 1584 ; 21764$ reflections collected with $2^{\circ}$ $<\theta<26^{\circ}, 3470$ unique $\left(\mathrm{R}_{\text {int }} 0.0264\right)$ used after correction for absorption $\left(\mathrm{T}_{\max , \min } 0.882\right.$,

0.686). Crystal dimensions $0.51 \times 0.18 \times 0.16 \mathrm{~mm}^{3}$. Refinement on $\mathrm{F}^{2}$ gave $\mathrm{R}_{1} 0.0356$ [I $>2 \sigma(\mathrm{I})]$ and $\mathrm{wR}_{2} 0.0782$ (all data), GoF 1.125 , residual peaks $\left( \pm 0.26 \mathrm{e} \AA^{-3}\right)$. The structure of 7 is illustrated in Figure 1, with selected bond parameters included in the caption to the figure.

\subsubsection{Structure of the $\eta^{5}$-azacyclohexadienyl complex $\boldsymbol{8} \boldsymbol{b}$}


Yellow needle crystals of $\mathbf{8 b}$ were obtained from petroleum spirits.

Crystal data: $\mathrm{C}_{26} \mathrm{H}_{18} \mathrm{MnNO}_{3}, \mathrm{M}=447.36$, monoclinic, space group $\mathrm{C} 2 / \mathrm{c}, \mathrm{a}=21.925(7), \mathrm{b}$ $=10.950(4), c=17.234(6) \AA, \beta=94.768(6)^{\circ}, U 4123(2) \AA^{3}, \mathrm{~T} 163 \mathrm{~K}, \mathrm{Z}=8, \mathrm{D}_{\text {calc }}=$ $1.441 \mathrm{~g} \mathrm{~cm}^{-3}, \mu(\mathrm{Mo}-\mathrm{K} \alpha)=0.67 \mathrm{~mm}^{-1}, \mathrm{~F}(000) 1840 ; 24528$ reflections collected with $2^{\circ}$ $<\theta<26^{\circ}, 4067$ unique $\left(\mathrm{R}_{\text {int }} 0.1033\right)$ used after correction for absorption $\left(\mathrm{T}_{\max , \min } 1.000\right.$, 0.826). Crystal dimensions $0.36 \times 0.18 \times 0.12 \mathrm{~mm}^{3}$. Refinement on $\mathrm{F}^{2}$ gave $\mathrm{R}_{1} 0.0416$ [I $>2 \sigma(\mathrm{I})]$ and $\mathrm{wR}_{2} 0.0450$ (all data), GoF 0.935 , residual peaks $\left( \pm 0.23\right.$ e $\left.\AA^{-3}\right)$. The structure of $\mathbf{8 b}$ is illustrated in Figure 2, with selected bond parameters included in the caption to the figure.

\section{Results and discussion.}

The reactions discussed in detail below are summarised in Scheme 1.
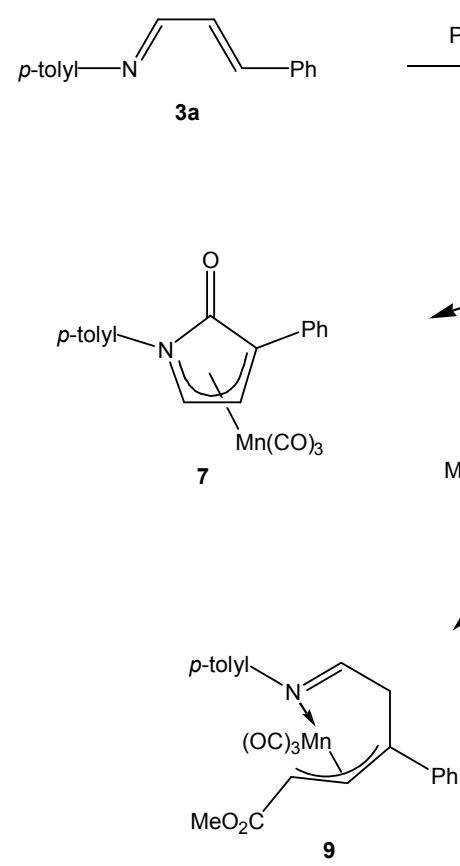
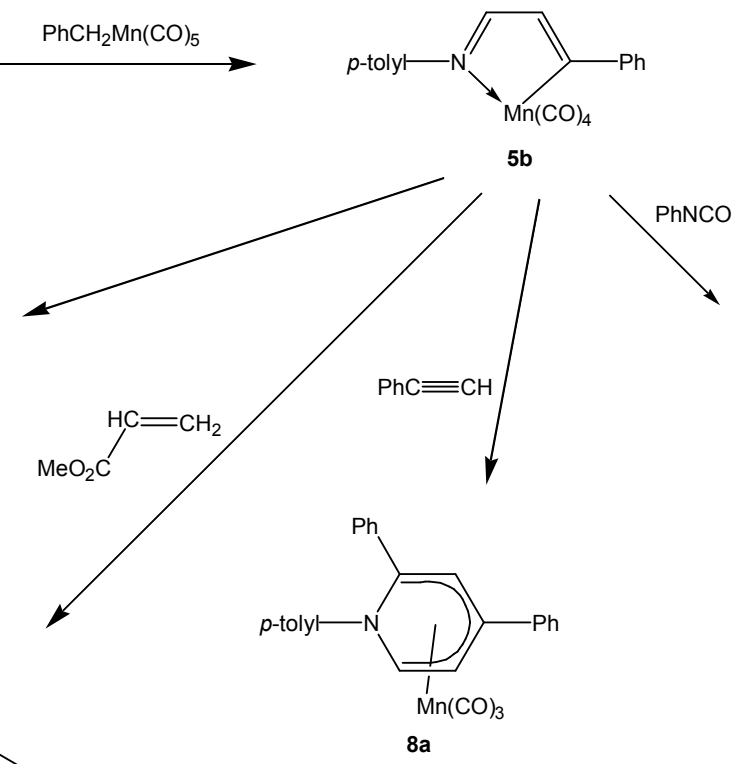

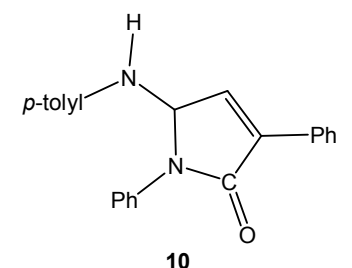

10

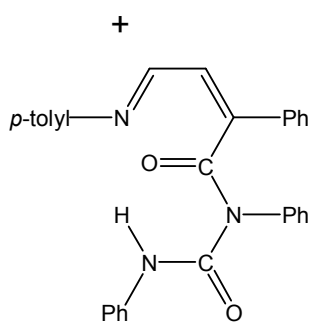




\subsection{Attempted cyclomanganation of 4-phenyl-1-p-tolyl-1-azabuta-1,3-diene.}

When the azabutadiene 3a was reacted with $\mathrm{PhCH}_{2} \mathrm{Mn}(\mathrm{CO})_{5}$, under the refluxingheptane conditions used successfully for cyclometallation of chalcones, a yellow product was readily isolated. Elemental analysis and ESMS were consistent with the expected product, a cyclometallated azabutadiene, but the infrared spectrum was not since the $v(\mathrm{CO})$ pattern was more like that of a $\mathrm{Mn}(\mathrm{CO})_{3}$ moiety than the characteristic $\mathrm{Mn}(\mathrm{CO})_{4}$ type.

An X-ray crystal structure determination was therefore carried out. This showed that a substituted pyrrolinonyl ring had formed and was coordinated to a $\mathrm{Mn}(\mathrm{CO})_{3}$ group as in 7. The structure is illustrated in Figure 1.

[Figure 1 near here]

Clearly the deprotonated azabutadiene group has combined with a CO ligand to form the new planar ring structure, and this acts as a five-electron donor to the manganese, with two electrons from the $\mathrm{N}$ atom, two from the $\mathrm{C}(4)-\mathrm{C}(5) \pi$ bond, and one from $\mathrm{C}(6)$. This leaves the $\mathrm{C}=\mathrm{O}$ group free of interaction with the manganese atom, although the Mn...C(7) is quite short (2.375 $\AA)$.

There appear to be no previous examples of $\eta^{4}$ - pyrrolinonyl complexes, the closest analogues being some $\eta^{2}$-pyrrolinone- $\mathrm{Fe}(\mathrm{CO})_{4}$ species [24]. This new synthesis of pyrrolinonyl rings is of interest as such five-membered rings are involved in several areas of organic chemistry [25], and different substituents could be incorporated by choosing the appropriate azabutadiene. 
A route to complex 7 can be proposed, by analogy with chalcone chemistry (Scheme 2) [13].

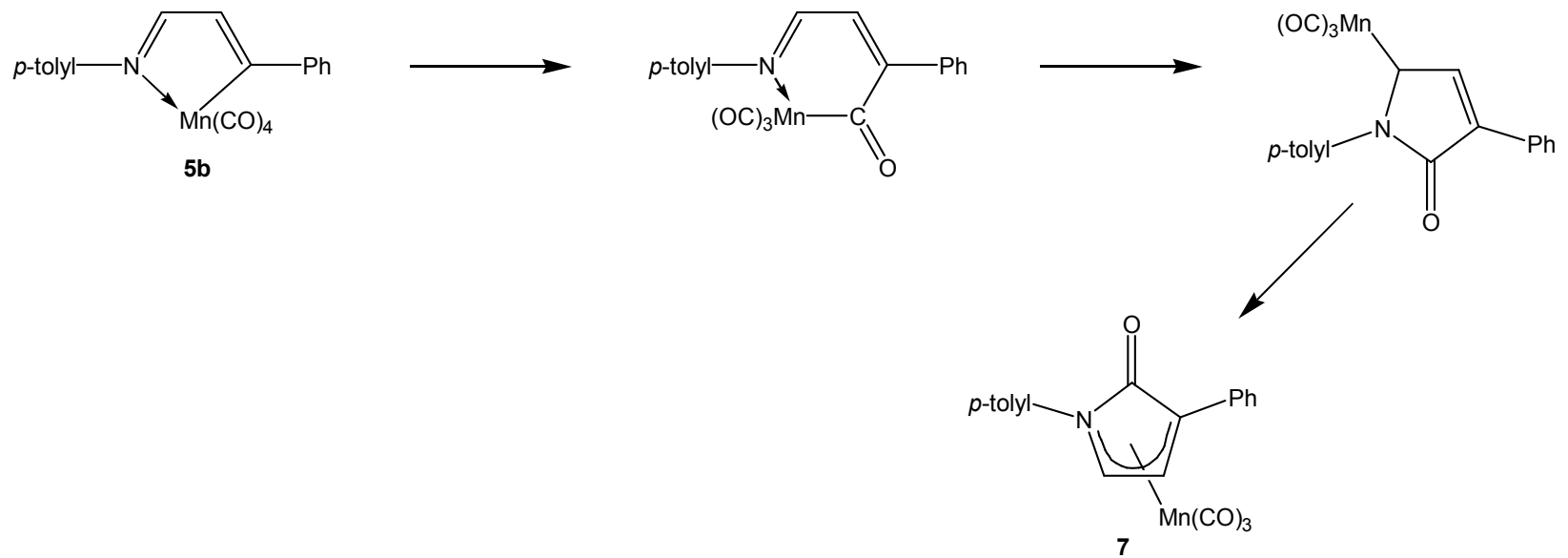

Scheme 2

The first step is presumably to form the cyclometallated azabutadiene $\mathbf{5 b}$. Under the conditions, and in contrast to chalcone examples, there is rapid insertion of a CO ligand into the $\mathrm{Mn}-\mathrm{C} \sigma$-bond. Addition of the new $\mathrm{Mn}-\mathrm{C}$ bond across the $\mathrm{N}=\mathrm{C}$ bond forms the five-membered ring with the $\mathrm{Mn}(\mathrm{CO})_{3}$ group attaching to one face in a $\eta^{4}$ manner to achieve an eighteen-electron configuration.

To investigate the reaction in more detail, it was repeated under milder conditions with monitoring by IR spectroscopy. When a mixture of the azabutadiene and $\mathrm{PhCH}_{2} \mathrm{Mn}(\mathrm{CO})_{5}$ was slowly heated in heptane, no change was observed until the temperature of the oil bath reached $70^{\circ} \mathrm{C}$, at which time two new IR peaks appeared at 2034 and $2076 \mathrm{~cm}^{-1}$. The former of these can be attributed to the pyrrolinonyl complex 7 , while the latter is in the position expected for the highest frequency $\mathrm{v}(\mathrm{CO})$ band for the 
cyclometallated azabutadiene $\mathbf{5 b}$ (c.f. $\sim 2080 \mathrm{~cm}^{-1}$ for cyclomanganated chalcones [12]). As the reaction continued the $2034 \mathrm{~cm}^{-1}$ peak increased, while that at $2076 \mathrm{~cm}^{-1}$ was never more than a small feature. This is consistent with the process in Scheme 2, where the cyclomanganated azabutadiene is formed, but rapidly reacts further by $\mathrm{CO}$ insertion.

\subsection{Reaction in the presence of $\mathrm{PhC} \equiv \mathrm{CH}$.}

Although the cyclomanganated complex $\mathbf{5 b}$ could not be isolated, its reactivity in situ with other substrates was of interest. Several groups have shown that reactions between cyclomanganated aryl ketones or chalcones and alkynes proceed via insertion/cyclisation processes to give novel derivatives $[8,13]$, so the corresponding reaction was investigated here. When a mixture of the azabutadiene $3 \mathbf{3 a}, \mathrm{PhCH}_{2} \mathrm{Mn}(\mathrm{CO})_{5}$ and $\mathrm{PhC} \equiv \mathrm{CH}$ ( $c$ a 1:1:3) was heated in petroleum spirits a reaction occurred to give a solution with $\mathrm{v}(\mathrm{CO})$ peaks indicative of a $\mathrm{Mn}(\mathrm{CO})_{3}$ group, but shifted $\sim 10 \mathrm{~cm}^{-1}$ to lower frequencies compared with those of the pyrrolinonyl-complex 7. Work-up provided two products. The major one was identified spectroscopically as the $\eta^{5}$-azacyclohexadienyl complex $\mathbf{8 a}$ formed in excellent yield.

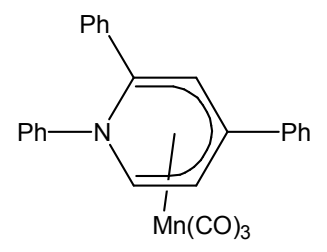

$8 b$

This is the $\mathrm{N}$-analogue of the $\eta^{5}$-pyranyl complexes formed when cyclomanganated chalcones are reacted with alkynes [13], and a similar route can be assumed. This invokes the cyclomanganated azabutadiene $\mathbf{5 b}$ as the first intermediate, which undergoes insertion 
of $\mathrm{PhC} \equiv \mathrm{CH}$ into the $\mathrm{Mn}-\mathrm{C}$ bond. Cyclisation involving the $\mathrm{N}=\mathrm{C}$ bond leads to the sixmembered ring with the $\mathrm{Mn}(\mathrm{CO})_{3}$ group occupying one face (Scheme 3).

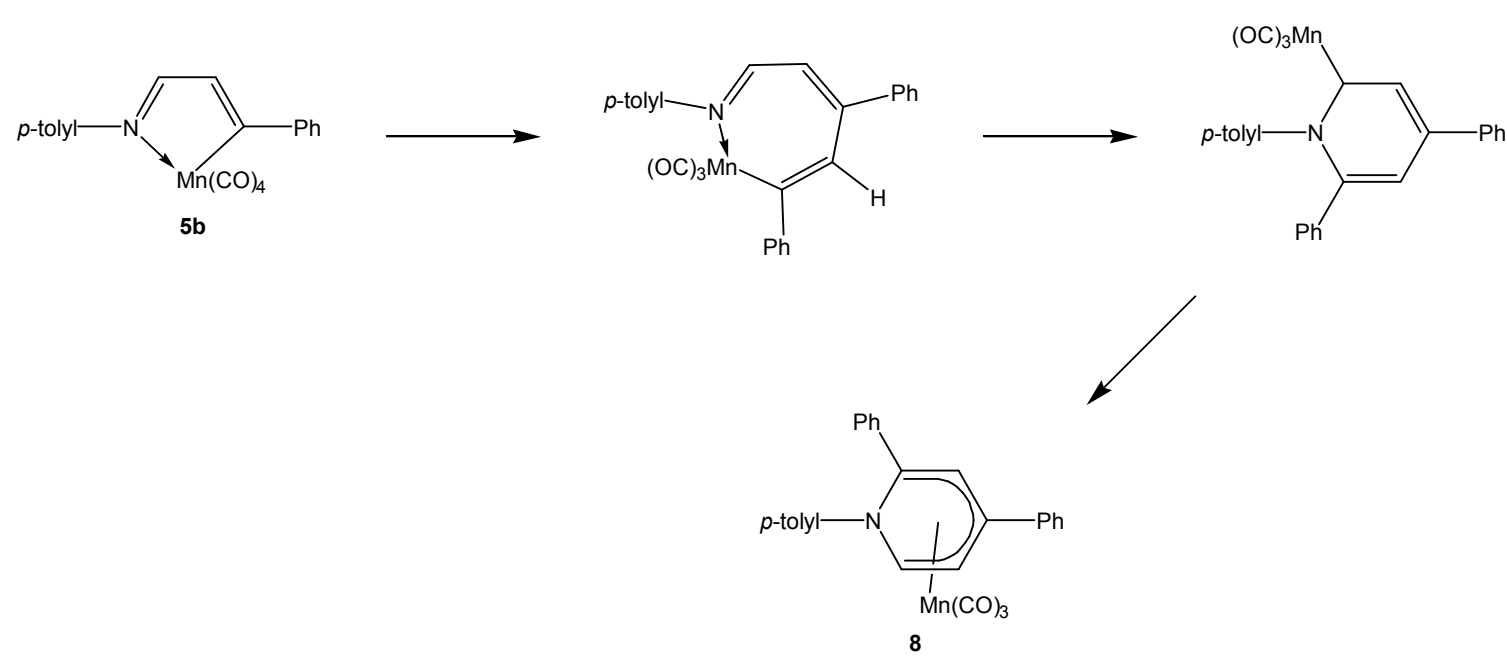

Scheme 3

The minor product from the reaction of the azabutadiene with $\mathrm{PhC} \equiv \mathrm{CH}$ was not identified, but appears to have arisen from $\mathrm{CO}$ insertion and double addition of $\mathrm{PhC} \equiv \mathrm{CH}$ to give a species which the mass spectrum suggests has an $M_{r}$ of 453 .

Compounds analogous to $\mathbf{8}$ have been prepared previously by reactions of alkynes with $\mathrm{RC}_{6} \mathrm{H}_{4} \mathrm{CH}_{2} \mathrm{C}(\mathrm{O}) \mathrm{Mn}(\mathrm{CO})_{4}\left(\mathrm{CNC}_{6} \mathrm{H}_{4} \mathrm{R}^{\prime}\right)$, probably via a cyclomanganated azabutadiene formed in situ by coupling the isonitrile with the first equivalent of alkyne [16]. Interestingly, the azacyclohexadienyl ligands found in that study were either $\eta^{4}$ or $\eta^{5}$, depending on the substituents. These cannot be distinguished reliably by spectroscopic means, but it seemed probable that 8a contained an $\eta^{5}$ ligand in the absence of electron-withdrawing substituents on the ring. We could not prepare crystals of $\mathbf{8 a}$ suitable for X-ray crystallography to confirm this, so the corresponding reaction using 1,4-diphenyl-1-azabutadiene was carried out. This gave $\mathbf{8 b}$ in a completely analogous 
procedure and this compound crystallised well. The structure of $\mathbf{8 b}$ is shown in Figure 2 and confirms the $\eta^{5}$-attachment of the ligand to the manganese.

[Figure 2 near here]

The $\mathrm{C}(1)$-C(5) atoms are planar to within $\pm 0.024 \AA$, forming a dihedral angle with the $\mathrm{C}(1)-\mathrm{N}(1)-\mathrm{C}(5)$ plane of $50^{\circ}$. The Mn-C bond distances range from 2.107(2)-2.202(3) $\AA$, average $2.146 \AA$, which indicates slightly stronger bonding of the ring than in the related $\left(\eta^{5} \text {-pyranyl)Mn(CO }\right)_{3}$ complexes where the average Mn-C distance was $2.188 \AA$ [13]. The structure of $\mathbf{8 b}$ is directly comparable to the $\eta^{5}$-azacyclohexadienyl examples with other substituents reported by Homrighausen et al [16].

\subsection{Reaction in the presence of $\mathrm{CH}_{2}=\mathrm{CHCOOMe}$.}

Activated alkenes are also known to react with cyclomanganated substrates derived from aryl ketones and chalcones [7, 13]. A mixture of the azabutadiene 3a, $\mathrm{PhCH}_{2} \mathrm{Mn}(\mathrm{CO})_{5}$ and $\mathrm{CH}_{2}=\mathrm{CHCOOMe}$ reacted to give one main product which was characterised spectroscopically as $\mathbf{9}$ in moderate yield. ESMS and elemental analysis confirmed the formula as a combination of one $\mathrm{CH}_{2}=\mathrm{CHCOOMe}$, one deprotonated azabutadiene molecule and one $\mathrm{Mn}(\mathrm{CO})_{3}$ fragment, while IR data confirmed a $\mathrm{Mn}(\mathrm{CO})_{3}$ unit and showed from the $v(\mathrm{C}=\mathrm{O})$ at $1734 \mathrm{~cm}^{-1}$ that the carboxylate group was not coordinated to the metal. A peak at $1699 \mathrm{~cm}^{-1}$ can be assigned to a non-conjugated $\mathrm{C}=\mathrm{N}$ bond. This information, and a full 2-D NMR study, leads to the structure 9, in which the $\mathrm{CH}_{2}=\mathrm{CHCOOMe}$ has coupled to the azabutadiene through C-4 to give a disubstituted methyl 7-azahepta-3,6-dien-2-yloate ligand. This is coordinated to the $\mathrm{Mn}(\mathrm{CO})_{3}$ group via an $\eta^{3}$-allyl interaction, with the remaining two electrons coming from the $\mathrm{N}$ atom. Again the formation of this species can be explained by initial formation of the 
cyclomanganated complex $\mathbf{5 b}$, followed by insertion of the alkene into the Mn-C bond and subsequent rearrangement giving the product. When an orthomanganated chalcone was reacted with $\mathrm{CH}_{2}=\mathrm{CHCOOMe}$ in $\mathrm{CCl}_{4}$ the main product was a substituted methyl 7oxo-hepta-2,6-dienoate, which is the protio-demetallated equivalent of 9 [12].

\subsection{Reaction in the presence of PhNCO.}

Liebeskind and co-workers reacted orthomanganated substrates with PhNCO and showed that insertion followed by cyclisation led to phthalimidines [9]. In the present system, $\mathrm{PhNCO}$ with $\mathrm{PhCH}_{2} \mathrm{Mn}(\mathrm{CO})_{5}$ and the azabutadiene gave two organic products, both in about $30 \%$ yield. The first of these showed an $[\mathrm{M}+\mathrm{H}]^{+}$peak at $m / z 341$ in the ESMS, giving a mass of 340 which corresponds to a combination of one $\mathrm{PhNCO}$ and one azabutadiene molecule. The IR spectrum showed a peak at $1715 \mathrm{~cm}^{-1}$ assigned to a free $\mathrm{C}=\mathrm{O}$ group, and the NMR spectra were consistent with the structure $\mathbf{1 0}$. This can be explained by an insertion of $\mathrm{PhNCO}$ into the $\mathrm{Mn}-\mathrm{C}$ bond of $\mathbf{5 b}$, followed by cyclisation involving the imine carbon atom to give a five-membered ring. Subsequent protiodemetallation would give $\mathbf{1 0 .}$

The other product from the reaction was shown to have a mass of 459 from ESMS. This equates to a combination of one azabutadiene molecule with two PhNCO molecules, presumably via a double insertion process. The IR spectrum contained three peaks in the $\mathrm{C}=\mathrm{O}$ or $\mathrm{C}=\mathrm{N}$ region. A possible structure is shown (11) but this could not be confirmed from NMR data so should be regarded as a tentative assignment only.

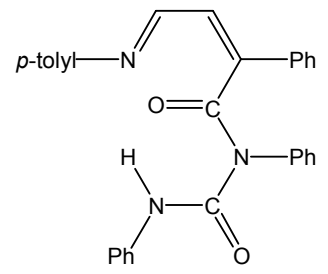

11

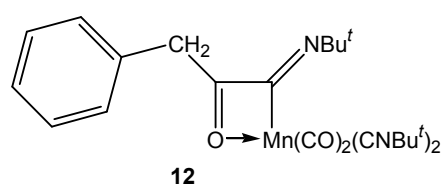

12

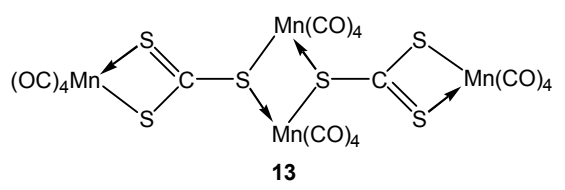




\subsection{Reaction in the presence of $B u^{t} N C$ or $C S_{2}$.}

These substrates were also examined as "one-pot" reagents. However in neither case were products derived from the azabutadiene isolated. $\mathrm{Bu}^{\mathrm{t}} \mathrm{NC}$ gave a low yield of a complex 12 which is not unexpected from a reaction between $\mathrm{PhCH}_{2} \mathrm{Mn}(\mathrm{CO})_{5}$ and an isonitrile, based on other studies of $\mathrm{RMn}(\mathrm{CO})_{5}$ compounds with isonitriles [26]. The formation of $\mathbf{1 2}$ involves stepwise insertion of first a $\mathrm{CO}$ ligand and secondly a $\mathrm{Bu}^{\mathrm{t}} \mathrm{NC}$ one, with further replacement of two terminal carbonyl groups by isonitriles. (An isomer of 12 with the inserted $\mathrm{CO}$ and $\mathrm{Bu}^{\mathrm{t}} \mathrm{NC}$ interchanged cannot be excluded spectroscopically, but is less likely.) It appears that isonitriles are too effective as Lewis bases and react with $\mathrm{PhCH}_{2} \mathrm{Mn}(\mathrm{CO})_{5}$ before the reaction with the azabutadiene to form 5b can take place.

In a rather unspecific reaction, $\mathrm{CS}_{2}$ gave a low yield of the trithiocarbonatetetramanganese compound $\mathbf{1 3}$, which has been found in similar reactions with other cyclomanganated substrates [11].

\subsection{Summary}

Although no cyclomanganated azabutadiene derivative $\mathbf{5 b}$ could be isolated, it appears that this is the first-formed compound in the reaction of $\mathbf{3 a}$ with $\mathrm{PhCH}_{2} \mathrm{Mn}(\mathrm{CO})_{5}$. This provides an activated form of the azabutadiene for subsequent coupling. A survey of "one pot" reactions between an azabutadiene and unsaturated substrates in the presence of $\mathrm{PhCH}_{2} \mathrm{Mn}(\mathrm{CO})_{5}$ shows that useful new compounds can be formed.

It is interesting that the three unsaturated molecules $\mathrm{PhC} \equiv \mathrm{CH}, \mathrm{CH}_{2}=\mathrm{CHCOOMe}$ and $\mathrm{PhNCO}$ all appear to insert initially into the $\mathrm{Mn}-\mathrm{C}$ bond of a pre-formed $\mathbf{5 b}$ to give a seven-membered metallocyclic ring intermediate, but that reactions then proceed 
differently. The alkyne-intermediate cyclises by attack at the imine nitrogen atom to give a six-membered ring, the PhNCO-intermediate attacks at the imine carbon atom to give a five-membered ring, while the alkene-derived species does not undergo a cyclisation reaction at all. Further work with other azabutadienes and other unsaturated molecules are underway to determine the factors that affect this reactivity.

\section{Supplementary material.}

Crystallographic data for the structural analyses have been deposited with the Cambridge Crystallographic Data Centre, CCDC nos 237998 and 237999. Copies of this information may be obtained free of charge from the Director, CCDC, 12 Union Rd., Cambridge CB2 1EZ, UK (Fax: +44-1223-336033; e-mail: deposit@ccdc.cam.ac.uk or www: http://www.ccdc.cam.ac.uk).

\section{Acknowledgements}

We thank Dr Jan Wikaira and Professor Ward Robinson, University of Canterbury, for collection of X-ray intensity data.

\section{References.}

1 L. Main and B. K. Nicholson, Adv. Metal-Org. Chem., 3 (1994) 1

2. R. J. McKinney, G. Firestein and H. D. Kaesz, Inorg. Chem., 14 (1975) 3066; J. M. Cooney, L. H. P. Gommans, L. Main and B. K. Nicholson, J. Organomet. Chem., 349 (1988) 197; J. M. Cooney, L. H. P. Gommans, L. Main and B. K. Nicholson, W. Tully, L. Main and B. K. Nicholson, J. Organomet. Chem., 634 (2001) 157. 
3. R. L. Bennett, M. I. Bruce, B. L. Goodall, M. Z. Iqbal and F. G. A. Stone, J. Chem. Soc., Dalton Trans., (1972) 1787; R. L. Bennett, M. I. Bruce and I. Matsuda, Aust. J. Chem., 28 (1975) 1265; C. Morton, D. J. Duncalf and J. P. Rourke, J. Organomet. Chem., 530 (1997) 19; A. Bohm, K.Sunkel, K. Polborn and W. Beck, J. Organomet. Chem., 552 (1998) 237.

4. R. G. Little and R. J. Doedens, Inorg. Chem., 12 (1973) 844; M. Pfeffer, E. P. Urriolabeitia and J. Fischer, Inorg. Chem., 34 (1995) 643.

5. G. J. Depree, N. D. Childerhouse and B. K. Nicholson, J. Organomet. Chem., 533 (1997) 143.

6. M. A. Leeson, B. K. Nicholson and M. R. Olsen, J. Organomet. Chem., 579 (1999) 243.

7. L. H. P. Gommans, L. Main and B. K. Nicholson, J. Chem. Soc., Chem. Commun., (1987) 761; R. C. Cambie, M. R. Metzler, P. S. Rutledge and P. D. Woodgate, J. Organomet. Chem., 429 (1992) 59.

8. L. S. Liebeskind, J. R. Gasdaska, J. S. McCallum and S. J. Tremont, J. Org. Chem., 54 (1989) 669; N. P. Robinson, L. Main and B. K. Nicholson, J. Organomet. Chem., 364 (1989) C37; R. C. Cambie, M. R. Metzler, P. S. Rutledge and P. D. Woodgate, J. Organomet. Chem., 429 (1992) 41.

9. L. S. Liebeskind, S. A. Johnson, J. S. McCallum, Tetrahedron Lett., 31 (1990) 4397.

10. J. M. Cooney, C. V. Depree, L. Main and B. K. Nicholson, J. Organomet. Chem., 515 (1996) 109. 
11. W. Mace, L. Main, B. K. Nicholson and M. Hagyard, J. Organomet. Chem., 664 (2002) 288 .

12. W. Tully, L. Main and B. K. Nicholson, J. Organomet. Chem., 503 (1995) 75.

13. W. Tully, L. Main and B. K. Nicholson, J. Organomet. Chem., 507 (1996) 103;

W. Tully, L. Main and B. K. Nicholson, J. Organomet. Chem., 633 (2001) 162.

14. L. H. Polm, W. P. Mul, C. J. Elsevier, K. Vrieze, M. J. N. Christopherson and C. H. Stam, Organometallics, 7 (1988) 423; W. P. Mul, C. J. Elsevier, W. J. J. Smeets and A. L. Spek, Inorg. Chem., 30 (1991) 4152; C. J. Elsevier, W. P. Mul and K. Vrieze, Inorg. Chim. Acta, 198 (1992) 689; W. Imhof, J. Chem. Soc., Dalton Trans., (1996) 1429.

15. R. D. Adams and M. Huang, Organometallics, 14 (1995) 506.

16. C. L. Homrighausen, J. J. Alexander and J. A. Krause Bauer, Inorg. Chim. Acta, 334 (2002) 419.

17. S. Tenreiro, G. Alberdi, J. Martinez, M. Lopez-Torres, J. M. Ortigueira, M. T. Pereira and J. M. Vila, Inorg. Chim. Acta, 342 (2003) 145.

18. W. Henderson, B. K. Nicholson and L. J. McCaffrey, Polyhedron, 17 (1998) 4291.

19 W. Henderson, J. S. McIndoe, B. K. Nicholson and P. J. Dyson, J. Chem. Soc., Dalton Trans., (1998) 519.

20. H-J. Knölker, G. Baum, N. Foitzik, H. Goesmann, P. Gonser, P. G. Jones and H. Röttele, Eur. J. Inorg. Chem., (1998) 993.

21. M. I. Bruce, M. J. Liddell and G. N. Pain, Inorg. Synth., 26 (1989) 172.

22. R. H. Blessing, Acta Cryst., A51, (1995) 33. 
23. G. M. Sheldrick, SHELX97 Programs for the solution and refinement of crystal structures, University of Gottingen, Germany, 1997.

24. R. Siebenlist, M. de Beurs, N. Feiken, H-W. Fruhauf and K. Vrieze, Organometallics, 19 (2000) 3032; A. D. Cuiper, M. Brzostowska, J. K.

Gawronski, W. J. J. Smeets, A. L. Spek, H. Hiemstra, R. M. Kellogg and B. L. Feringa, J. Org. Chem., 64 (1999) 2567.

25. D. Witthaut, R. Frohlich and H. J. Schafer, Angew. Chem. Int. Ed. Eng., 40 (2001) 4212.

26. P. L. Motz, J. J. Alexander and D. M. Ho, Organometallics, 8 (1989) 2589; D. W. Kuty and J. J. Alexander, Inorg. Chem., 17 (1978) 1489; P. L. Motz, J. P. Williams, J. J. Alexander, D. M. Ho, J. S. Ricci and W. T. Miller, Organometallics, 8 (1989) 1523; T. M. Becker, J. J. Alexander, J. A. Krause Bauer, J. L. Nauss and F. C. Wireko, Organometallics 18 (1999) 5594. 


\section{Captions to figures.}

Figure 1. The structure of the $\eta^{4}$-1-tolyl-3-phenylpyrrolin-2-onyl-manganese tricarbonyl complex 7 .

Bond lengths include: $\mathrm{Mn}(1)-\mathrm{N}(1)$ 2.102(2), Mn-C(4) 2.080(2), Mn-C(5)

2.131(2), Mn-C(6) 2.195(2), Mn...C(7) 2.375(2), C(7)-O(4) 1.214(2), C(4)$\mathrm{C}(5)$ 1.394(3), C(5)-C(6) 1.421(3) $\AA$.

Figure 2. The structure of the 1,2, 4-triphenyl-1-azacyclohexa-2,4-dien-6-ylmanganese tricarbonyl complex 8b. Bond lengths include: $\mathrm{Mn}(1)-\mathrm{C}(1)$ 2.202(2), Mn-C(2) 2.121(2), Mn-C(3) 2.160(3), Mn-C(4) 2.107(3), MnC(5) 2.142(3), C(1)-N(1) 1.453(3), C(5)-N(1) 1.429(3), C(11)-N(1) $1.420(3) \AA$. 


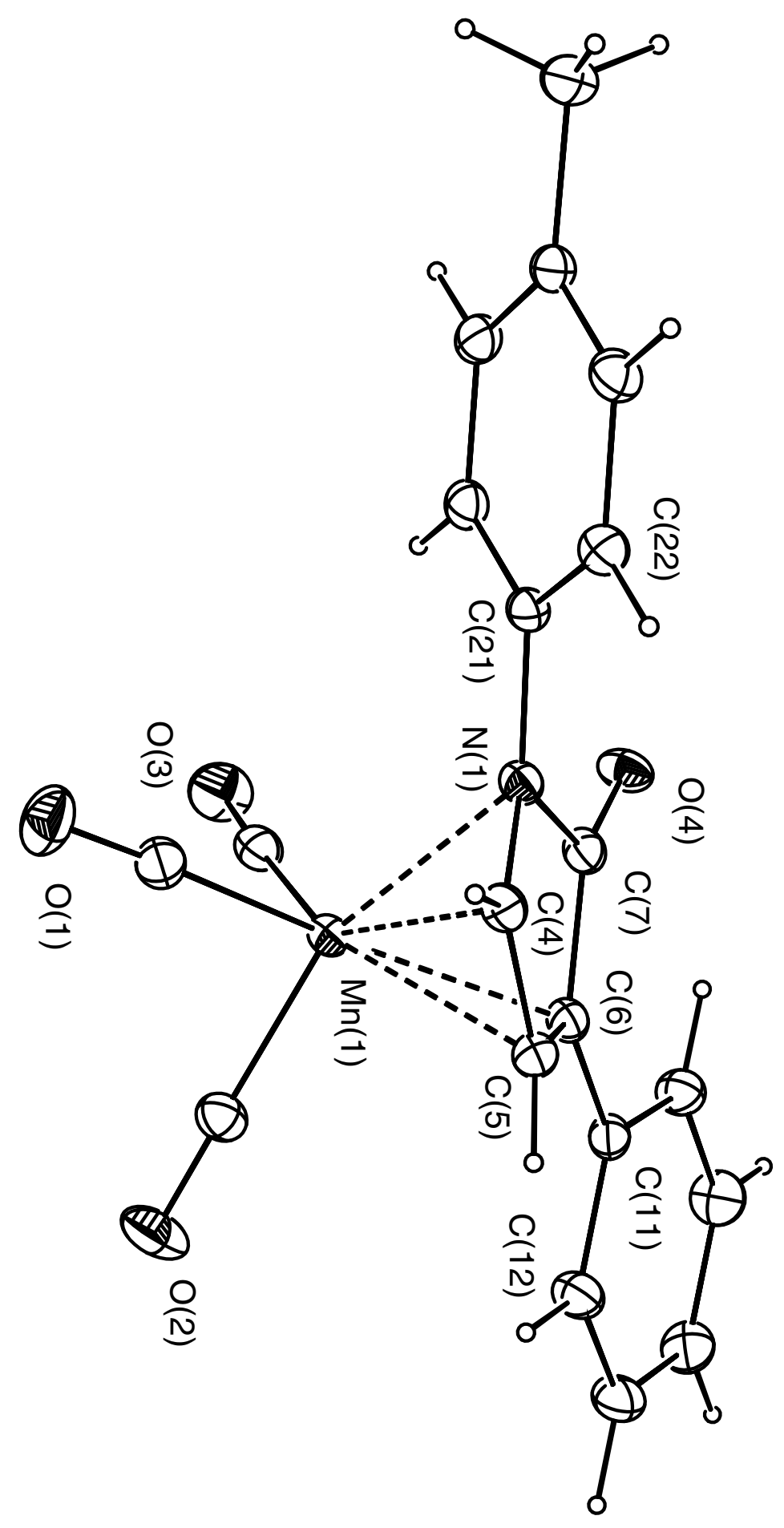




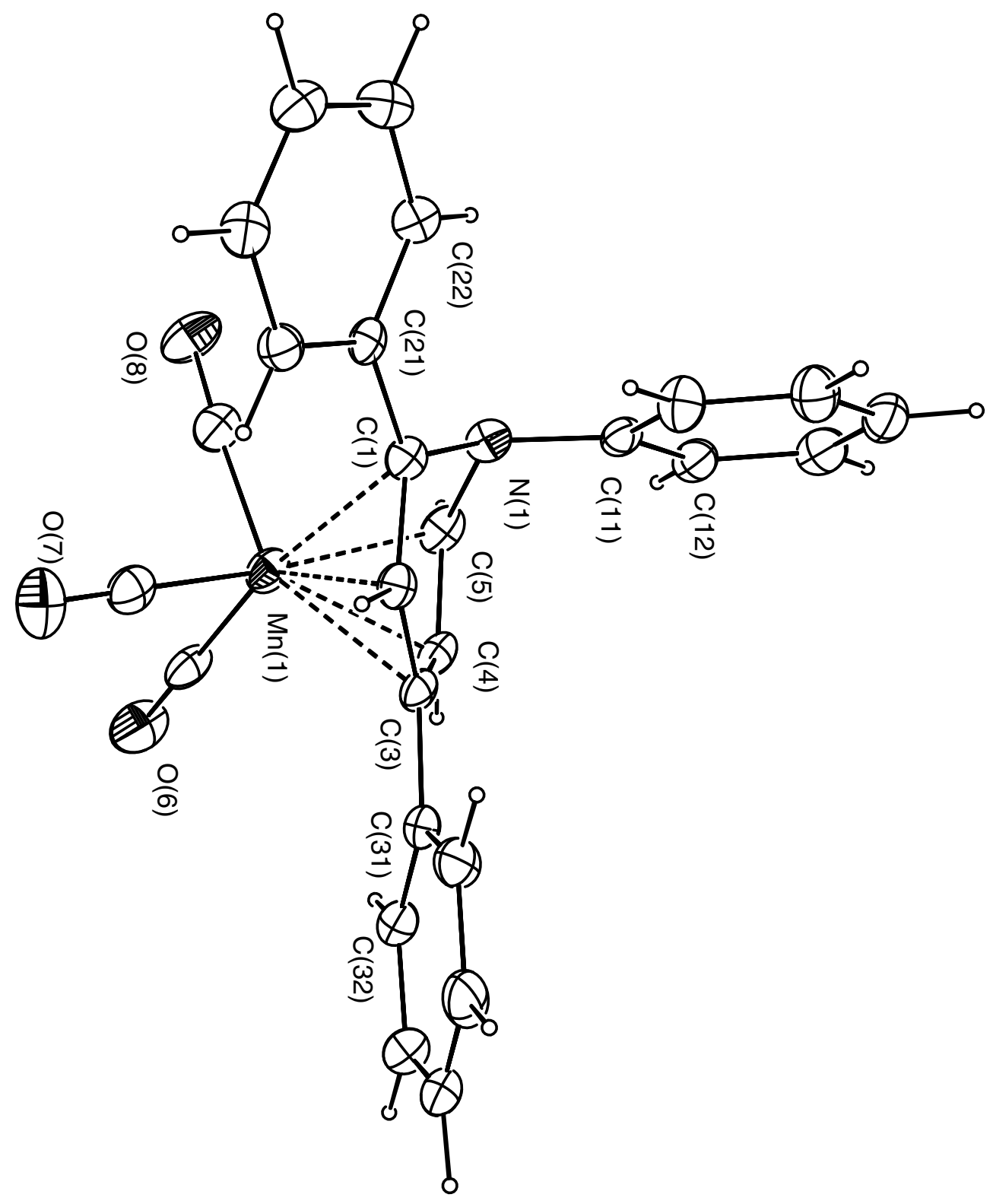

